\title{
Hip Hop on Film: Performance Culture, Urban Space, and Genre Transformation in
} the 1980s.

By Kimberly Monteyne. Jackson, MS: University Press of Mississippi, 2013. Pp. x, 256. \$54; Kindle \$37.19.

I have loved watching movies for as long as I can remember. As a small child, I sat in front of the television watching classic black and white film. Many of my teen years were spent at the movie theater or plastered in front of a television watching $\mathrm{HBO}$ and Cinemax. Present day, the same can be said for Netflix, Youtube.com and me. Musicals, independent, foreign, thrillers, avant-garde, and documentaries, are the genres I look for first when making a selection. I was delighted, to say the least, to read Hip Hop on Film, Performance, Culture, Urban Space and Genre Transformation in the 1980s. The book introduced me to classic movies that I was able to find and watch while reminding me of other movies I watched years ago. Enthralled in Hip Hop on Film, I was inspired to multitask - reading and taking notes while watching Hip Hop musicals.

Beginning with pre-Hip Hop musical influencers, author Kimberly Monteyne describes African American roles in films that date back to the early 20th century. Monteyne points out how in the initial days of film, strategically placed Black performers in musicals could be edited out to suit Southern movie theater owners and their patrons. The essence of the book explores a lesser-known category of Hip Hop musicals as a genre that has its role in film history.

As Monteyne explains in the introduction, Hip Hop culture has made a mark in society, academia, and the movie industry. Underground messages of societal woes from Latino and African American performers were performed in movie theaters. Higher education took note of the culture and its effects. Accordingly, film producers featured Latino and African American street performers alongside performers who were considered a part of a more disciplined art form. Some Hip Hop films of the genre included rappers with political messages.

Hip Hop music and Hip Hop musicals were not widely viewed among mainstream audiences thirty-five years ago. Through rapping, DJing, graffiti writing, and break dancing, these musicals helped to spread the message of disenfranchised urban youth to people all over the world.

Monteyne proves early on in the book that Hip Hop movies have elements consistent with the musical genre. In chapter one, Monteyne lists several Hip Hop themed features that contain elements of musicals. Reminded of the names of such musicals, Wild Style and Flashdance are two Hip Hop musicals available for view on Netflix. Free viewing of Rappin', Breakin', and Body Rock are available on Youtube.com. Other Hip Hop movies mentioned in the book are available at a cost on Youtube.com.

Although earlier films that included African American actors were explored, Hip Hop on Film delves into a side to musicals that mainstream moviegoer were not 
accustomed to in the 1980s. Hip Hop musicals in Hip Hop on Film shows a side of life unfamiliar to many who neither lived in nor visited an urban community.

Dilapidated buildings, poor living conditions, graffiti spray-painted on walls and trains, and people breakdancing on the street make some Hip Hop musicals different from musicals audiences were accustomed to seeing. While watching some of these films years ago, musical was not the category I would have placed Hip Hop movies. Armed with a different perspective, watching these Hip Hop movies again took on a new meaning. Hip Hop musicals tell a part of the story through rapping, breaking, graffiti writing and DJing.

Musicals (as we know it) tell a part of the story through songs, dance, and orchestra. Consequently, Monteyne notes Hip Hop movies also included the conflict, the love story, and the music and dance aspects that classical musicals use.

Social issues were significant to the 1980s Hip Hop culture. It seems befitting to include social issues in Hip Hop musicals. Monteyne makes a distinction between "true Hip Hop musical" - and "surface Hip Hop musical" (p. 47). These terms are significant to readers of the book who are unfamiliar with each movie discussed. When viewing this style of movie, the terms help one put each movie into perspective. Then the viewer can determine if the movie is truly a Hip Hop musical.

Wild Style (1983) is referred to throughout the book, but chapter two focuses solely on the Hip Hop movie and its impact as a musical. Pointing out the central character is neither a rapper nor dancer, the movie features several full rap songs performed by rap artists. Also featured were choreographed performances by breakdancers. Comparing to elements of classical musicals, Monteyne describes what sets Wild Style apart from all musicals.

Ever since there have movie theaters, there have been films that pack in droves of teenagers. Trendy teens often mimicked what they saw on the big screen. Teens were influenced by big screen fashion. The 1980s brought about different scenarios for the younger crowd. Many of the movies were about beautiful people and their beautiful lifestyles - rich kids living in the suburbs. There was little diversity in those films 30 to 40 years ago. However, scenes from Hip Hop musicals were not perfect or filled with beautiful people living in beautiful homes.

Chapter three, Hip Hoppers and Valley Girls, discusses how films that included rapping, breaking, and DJing launched trends. While mainstream movies showed scenes where youth spent time at the mall; Hip Hop musicals of the era sent another message. Urban youth musicals expressed levels of creativity through performance on walls and trains and street and club.

Additionally, the book quantifies 1980s Hip Hop movies alongside favorite mainstream movies targeting teens. Movie houses with multiple theaters attracted under one roof crowds of people interested in mainstream movies and Hip Hop movies. Hip Hop on Film notes the popularity of the Hip Hop style musical. Eventually, some of these types of movies became box office hits and influenced a later more successful musical with a female lead character, which was not seen in earlier Hip Hop musicals. Flashdance featured a female lead character trying to move from club 
performances to classical performances with the ballet. That is the gist of chapter four diverse contributions in Hip Hop film. While men were featured performers in most Hip Hop musicals, Monteyne notes the impact women had behind the scenes. The author names specific women who were important in the breakdance choreography for these film.

All four chapters of Hip Hop on Film include pertinent details that ascribe to the relevance of Hip Hop musical history. The diversity aspect is evident as Monteyne discusses race, gender, socio-economic background and social and political stances. The book is an informative read of historical value to a variety field of studies. Monteyne makes a persuasive case for the Hip Hop musical in this well-researched text.

Renette Smith McCargo is an Academic Advisor and Career Coordinator for the College of Media and Communication and adjunct instructor in the Department of Media at Arkansas State University. Her research interests include the portrayal of print literacy in children's television programming, eWord of Mouth or consumer-generated content in social media and cyberbullying.

\section{Policing the Campus: Academic Repression, Surveillance, and the Occupy Movement.}

Edited by Anthony J. Nocella II and David Gabbard. New York, N.Y.: Peter Lang, 2013. Pp. vii, 223. Paperback $\$ 39.95$

In fourteen chapters there is solid evidence of there being increased policing and surveillance on college and university campuses in California, Indiana, Virginia, Illinois and across the nation.

Some of the documented evidence shows the policing of campuses to the point of arrests, tasers, and pepper spray. This evidence also shows the increase in the use of surveillance cameras along with campus-wide alert systems that also can be used for surveillance.

Jason Del Gandio, one of the article researchers, wrote, “...it is obvious that student protets are commonly met with police repression. More times than not, school administrations authorize such repression" (p. 6).

First, the photo on the cover of the book gives a clear indication that police and law enforcement are pretty much the bad guys, the terrorists, in these case studies and articles. The photo is of a police officer pepper spraying some students who are sitting on the sidewalk. The photo also shows how any and everybody with a camera these days can capture what is happening. There are four cell phones and tablets and three cameras visibly capturing the event.

Also, the book's dedication sets the tone for the body of work. In part it says, "This book is for all of those who demand a free democratic critical inclusive education for social justice, void of guns, police, security, and surveillance." 